\title{
Kegiatan Pendistribusian Zakat Produktif Pemberdayaan UMKM Di LAZIZMU Kabupaten Gresik
}

\author{
Ayu Rahmatul Ainiyah ${ }^{1}$, Airlangga Bramayudha ${ }^{2}$ \\ ${ }^{1,2}$ Universitas Islam Negeri SunanAmpel Surabaya \\ 1Ayu.rahnia@gmail.com, ${ }^{2}$ Bram@uinsby.ac.id
}

\begin{tabular}{l}
\hline Article Info \\
\hline Article history: \\
Received 15 Mei 2021 \\
Accepted 15 Juni 2021 \\
Published 25 Juli 2021 \\
Page : 91 - 108 \\
\hline
\end{tabular}

Keyword:

Pendistribusian, Zakat Produktif

\begin{abstract}
This study aims to determine the form of productive zakat distribution activities for empowering MSMEs in LAZISMU Gresik district and determine several factors that influence the effectiveness of these activities. This research used descriptive qualitative reseacrh method. Qualitative descriptive was used to descriptive and examine in depth the form of productive zakat distribution activites for empowering MSMEs in LAZISMU district and the factors that influenced the effectiveness of these activities. Them, the data collection technique was carried out by means of interviews, observations, and documentation. The results of this study were as follows. First, the activity that moved to increase community potentiol in the Economic field. There were certain rules that had to be followed In this activity. Among them were the distribution system, the form of zakat distribution, the distribution pattern, the criteria for productive zakat recipient groups to the stages or procedure for disturbing zakat potential beneficiaries. Second, there were several factors that influenced the productive zakat distribution activities for the empowerment of MSMEs in LAZISMU Gresik regency. Among them were goal setting, human resource search and utilization, achievement environment, communication process, leadership and decision making, and innovation.
\end{abstract}

Penelitian ini bertujuan untuk mengetahui bentuk kegiatan pendistribusian zakat produktif pemberdayaan UMKM di LAZISMU kabupaten Gresik dan mengetahui beberapa faktor yang mempengaruhi efektivitas dari kegiatan tersebut. Penelitian ini menggunakan metode penelitian deskriptif kualitatif. Metode penelitian ini untuk menggambarkan dan meneliti secara mendalam tentang bentuk kegiatan pendistribusian zakat produktif pemberdayaan UMKM di LAZISMU kabupaten Gresik dan faktor-faktor yang menjadi pengaruh efektivitas dari kegiatan tersebut. Kemudian, teknik pengumpulan data dilakukan dengan media wawancara, observasi, dan dokumentasi. Hasil penelitian ini adalah sebagai berikut. Pertama, bentuk kegiatan bergerak untuk meningkatkan potensi masyarakat dalam bidang ekonomi. Dalam kegiatan tersebut memiliki beberapa aturan yang harus dijalankan. Diantaranya adalah sistem pendistribusiannya, bentuk pendistribusian zakatnya, pola pendistribusiannya, kriteria golongan penerima zakat produktif hingga tahapan pendistribusian zakat kepada para calon penerima manfaat. Kedua, ada beberapa faktor yang mempengaruhi kegiatan pendistribusian zakat produktif pemberdayaan UMKM di LAZISMU Kabupaten Gresik. Diantaranya adalah penetapan tujuan, pencarian dan pemanfaatan SDM, lingkungan prestasi, proses komunikasi, kepemimpinan dan pengambilan keputusan, serta inovasi.

Copyright (C) 2021 Journal Of Islamic Management 


\section{Pendahuluan}

Pendistribusian adalah proses penyaluran suatu barang ataupun jasa dari tempat satu ke tempat yang lain. Indrajit dan Pranoto mendefinisikan bahwa distribusi merupakan suatu proses penyampaian produk. Proses penyampaian tersebut dimulai dari produsen utama. Produsen utama bertugas untuk memproduksi barang atau jasa. Kemudian keduanya disalurkan kepada pemakai akhir. ${ }^{1}$ Tjiptono juga menjabarkan bahwa pendistribusian diartikan sebagai kegiatan pemasaran. Kegiatan pemasaran bertujuan untuk memperlancar dan mempermudah penyampaian barang atau jasa dari produsen kepada konsumen. Sehingga, para konsumen menggunakan kebutuhannya sesuai yang diperlukan. ${ }^{2}$

Tujuan pendistribusian merupakan suatu kewajiban manusia atau pemerintah sebagai pemimpin dalam pemberdayaan sumber daya yang ada. Sehingga, hal tersebut akan menghasilkan kemakmuran serta niat untuk mencari ridha Allah swt dan saving di hari akhirat kelak. ${ }^{3}$ Oleh karena itu, jika sistem pendistribusian dalam sebuah organisasi dilakukan secara benar, maka dampaknya akan membawa perubahan dalam masyarakat.

Pendistribusian zakat merupakan kegiatan penyaluran zakat yang diberikan kepada pihak-pihak tertentu. Erland Arif mendefinisikan bahwa pendistribusian zakat adalah suatu proses penyaluran dana

1 Merry Agustina, Fina Oktasari. Penerapan Metode DRP (Distribusi Requirement Planning) Pada Sistem Informasi Distribusi LPG (Studi Kasus - PT Bumi Sriwijaya Palembang). Seminar Nasional Informatika UPN "Veteran” 2012. Vol.1 No.4. Yogyakarta 30 Juni 2015. Hal 77

2 Imam Heryanto. Analisis Pengaruh Produk, Harga, Distribusi, dan Promosi Terhadap Keputusan Pembelian Serta Implikasinya Pada Kepuasan Pelanggan. Jurnal Ekonomi, Bisnis, dan Entrepreneurship. Vol.9 No.2. Oktober 2015. Hal 80-101

3 Ahmad Dahlan. 2008. Keuangan Publik Islam: Teori dan Praktik. (Yogyakarta:Grafindo Litera Media). Hal 56 zakat yang dikumpulkan dan diberikan kepada pihak-pihak tertentu. Hal tersebut bermaksud untuk meraih tujuan Sosial dan Ekonomi dari pemungutan zakat. ${ }^{4}$ Adapun pendistribusian zakat juga dijelaskan dalam Al-Qur'an surah At-Taubah ayat 60:

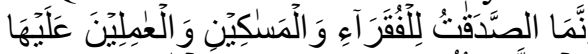

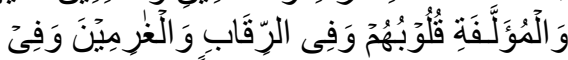

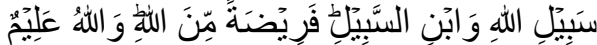
حَكِيِْ

Artinya : "sesungguhnya zakat itu hanyalah untuk orang-orang fakir, orang miskin, amil zakat, yang dilunakkan hatinya (mualaf), untuk (memerdekakan) hamba sahaya, untuk (membebaskan) orang yang berutang, untuk jalan Allah, dan untuk orang yang sedang dalam perjalanan, sebagai kewajiban dari Allah. Allah Maha Mengetahui, Maha Bijaksana". 5

Ayat tersebut menjelaskan delapan golongan penerima zakat. Diantaranya adalah fakir, miskin, amil atau pengurus zakat, mualaf, riqab, gharimin, sabilillah, dan ibnu sabil. Jika pendistribusian zakat perintah zakat dilakukan dan diberikan kepada golongan sesuai dengan hukum syara', maka hal tersebut akan mendatangankan kemaslahatan. Namun, jika perintah zakat tidak dilakukan, maka hal tersebut termasuk pelanggaran akan hukum Allah sesuai dalam Al-Qur'an dan As-Sunnah. ${ }^{6}$ Pendistribusian zakat kini

4 Jeni rahman, Evi Martaseli. Pengaruh Pengendalian Internal Terhadap Pengelolaan dan Pendistribusian Zakat Pada Badan Amil Zakat Nasional Kota da Kabupaten Sukabumi. Jurnal Ilmiah Ilmu Ekonomi. Vol.6 Edisi.12. Maret 2018. Hal 179

${ }^{5}$ https://tafsirweb.com/3076-quran-surat-at-taubahayat-60.html pada tanggal 10 Desember pukul $10: 36$

${ }^{6}$ Emi Hartatik. Analisis Praktik Pendistribusian Zakat Produktif Pada Badan Amil Zakat Daerah (BAZDA) Kabupaten Magelang. Az-Zarqa. Vol.7 No.1. Juni 2015. Hal 30 
mengalami banyak perubahan seiring perkembangan zaman yang semakin modern. Pada umumnya, pendistribusian zakat dilakukan dengan memberikan dana yang bersifat konsumtif. Namun, kini pendistribusian zakat juga dilakukan dengan memberikan dana zakat yang bersifat produktif. Tujuannya adalah untuk meningkatkan kesejahteraan para mustahik. Sehingga, para mustahik mampu berkembang dan mengubah kondisi baik dari sisi Sosial ataupun Ekonominya.

Zakat produktif merupakan penyerahan sejumlah barang kepada penerima dan mampu untuk menghasilkan nilai tambah secara terus-menerus. ${ }^{7}$ Asnaini mengungkapkan bahwa zakat produktif adalah pemberian zakat yang mampu menghasilkan secara terusmenerus kepada para penerimanya. ${ }^{8}$ Sartika menambahkan bahwa pengembangan zakat produktif mampu mengubah dana zakat sebagai modal usaha. Modal usaha tersebut dijadikan sebagai pemberdayaan ekonomi penerimanya. Hal tersebut bertujuan untuk membantu fakir miskin dalam pemenuhan hidupnya dengan konsisten. Karena melalui dana tersebut, para musthaik akan memiliki pendapatan yang tetap. Selain itu, mereka juga mampu untuk meningkatkan dan mengembangkan usahanya. ${ }^{9}$ Dalam penelitian ini, peneliti mengambil objek di Lazismu Kabupaten Gresik.

Lembaga Amil Zakat Infaq dan Shadaqah Muhammadiyah Kabupaten Gresik (LAZISMU) merupakan lembaga resmi penyalur dana zakat, infaq, dan shadaqah serta dana kedermawanan lainnya. Lembaga tersebut dibentuk oleh SK Pimpinan Daerah Muhammadiyah

\footnotetext{
${ }^{7}$ Ibid. Hal 32

${ }^{8}$ Tika Widiastuti. Model Pendayagunaan Zakat Produktif Oleh Lembaga Zakat Dalam Meningkatkan Pendapatan Mustahik. JEBIS. Vol.1 No.1.2015. Hal 94
}

Kabupaten Gresik No.89/10 tanggal 24 Juli 2010. Setiap lembaga tentu memiliki visi dan misi. Visi Lazismu yaitu menjadi lembaga amil zakat yang terpercaya. Lazismu juga memiliki tiga misi. Diantaranya adalah pertama, optimalisasi kualitas pengelolahan ZIS yang amanah, profesional, dan transparan. Kedua, optimalisasi pendayagunaan ZIS yang kreatif, inovatif, dan produktif. Ketiga, optimalisasi pelayanan donatur. Struktur organisasi Lazismu terbagi menjadi 4 macam. bagian tersebut adalah dewan syari'ah, badan pengawas, badan pengurus, dan badan eksekutif. Lazismu juga bergerak dalam beberapa program. diantaranya adalah program pendidikan, ekonomi, sosial, dan dakwah. ${ }^{10}$ Lazismu merupakan lembaga cabang daerah dengan karyawan yang minim. Namun, Lazismu telah dikenal dengan lembaga amil zakat yang efektif baik dari pengelolaan dan pendistribusian dana ZIS.

Lazismu Kabupaten Gresik mempunyai keunikan dalam bidang pendistribusian zakat. Selain sistemnya menggunakan based on pengajuan, program pendistribusian zakat dikatakan efektif dan efisien meskipun program tersebut hanya dikerjakan oleh karyawan yang minim. Dari beberapa kegiatan di program pendistribusian zakat tersebut bernilai guna bagi masyarakat. Contoh salah satu kegiatan di program pendistribusian zakat adalah kegiatan pemberdayaan UMKM. Kegiatan tersebut merupakan kegiatan penyaluran dana zakat yang bersifat produktif. Kegiatan pemberdayaan UMKM bertujuan untuk meningkatkan kesejahteraan masyarakat baik dari sisi sosial, dakwah, ataupun ekonomi. kegiatan pemberdayaan UMKM

\footnotetext{
${ }^{9}$ ibid

10 https://azismugresik.org pada tanggal 10 Desember 2020 pukul 11:19
} 
bergerak dalam pemberian modal usaha dan penguatan usaha. Caranya adalah dengan penguatan skema kemitraan kepada individu atau kelompok.

Dari keterangan diatas dapat disimpulkan bahwa minimnya karyawan dalam sebuah organisasi tidak selalu dipandang kecil dan sebelah mata. Lazismu merupakan contoh salah satunya. Lazismu memang hanya mempunyai karyawan yang minim. Namun, program yang dijalankan bisa dinilai efektif bagi masyarakat terutama dalam kegiatan pemberdayaan UMKM penyaluran dana zakat produktif. Karena, kegiatan tersebut telah memberikan perubahan bagi para mustahik. Kini para mustahik produktif mengelola usaha dan hidup mandiri. Dalam penelitian ilmu manajemen hanya mengakaji tentang dampak efektivitas dan efisiensi suatu hal. Oleh karena itu, peneliti tertarik untuk meneliti kegiatan pemberdayaan UMKM Lazismu Kabupaten Gresik. Tujuannya adalah untuk mengetahui hal-hal yang menyebabkan efektivitas jalannya suatu kegiatan dan hasil dari kegiatan tersebut bagi masyarakat.

\section{Kajian Pustaka}

\section{Pendisitribusian}

\section{a. Definisi Distribusi}

Distribusi merupakan proses penyaluran barang dari produsen ke tangan konsumen. Kegiatan distribusi bertujuan untuk menyalurkan barang atau jasa ke tangan konsumen dengan tepat waktu. Oleh karena itu, kegunaan barang dan jasa mempunyai nilai tambah setelah dikonsumsi. Hal

11 Westriningsih. 2018. Mengenal Kegiatan Distribusi. Klaten:Cempaka Putih. Hal 5

12 Emi Hartatik. Analisis Praktik Pendistribusian Zakat Produktif Pada Badan Amil Zakat Daerah (BAZDA) Kabupaten Magelang. Az-Zarqa. Vol.7 No.1. Juni 2015. Hal 33 tersebut menunjukkan bahwa distribusi bisa meningkatkan kegunaan barang dan jasa menurut tempat (place utility) dan waktu (time utility). Jika kegiatan distribusi tidak dilakukan, maka suatu barang menjadi tidak bernilai. ${ }^{11}$

\section{b. Jenis-Jenis Distribusi}

1). Sistem Distribusi Langsung

Sistem distribusi langsung adalah sistem distribusi yang tidak menggunakan atau perantara.

2). Sistem Distribusi Tidak Langsung

Sistem disribusi tidak langsung merupakan sistem distribusi yang menggunakan saluran distribusi dalam kegiatan pendistrubusiannya. Dalam pendistribusian ini terdapat pedagang perantara seperti agen atau pengecer.

\section{Pendistribusian Zakat}

\section{a. Definisi}

Pendistribusian zakat merupakan suatu kegiatan atau aktivitas penyaluran dana zakat dari muzakki kepada mustahik. penyaluran dana zakat tersebut dilakukan dengan menerapkan fungsi manajemen. Sehingga, tujuan organisasi bisa tercapai secara efektif. ${ }^{12}$

\section{b. Tujuan}

Tujuan distribusi zakat terbagi menjadi dua yakni: ${ }^{13}$

1). Kekayaan tidak menjadi terpusat dan tersebar hanya di sebagian kecil masyarakat. akan tetapi, kekayaan bisa tersebar secara

13 Teguh Ansori. Pengelolahan Dana Zakat Produktif Untuk Pemberdayaan Mustahik Pada Lazisnu Ponorogo. Muslim Heritage. Vol.3 No.1. Mei 2018. Hal 172 
terus-menerus kepada masyarakat.

2). Faktor-faktor produksi bersumber dari kekayaan nasional. Hal tersebut harus dibagi secara adil kepada masyarakat.

3). Perbedaan kaya dan miskin dihapuskan. Sehingga, hal tersebut berfungsi sebagai jaminan sosial dan persatuan masyarakat dalam pemenuhan kebutuhan-kebutuhan individu.

\section{c. Bentuk-Bentuk Pendistribusian Zakat}

M. Arif Mufraini berpendapat bahwa bentuk inovasi distribusi zakat terbagi menjadi empat macam yaitu: ${ }^{14}$

1). Ditribusi konsumtif tradisional, distribusi tersebut dibagikan untuk dimanfaatkan secara langsung. Contohnya adalah zakat fitrah dan zakat mal.

2). Distribusi konsumtif kreatif, distribusi tersebut diberikan dalam bentuk barang. Contohnya adalah alat-alat sekolah dan beasiswa.

3). Distribusi produktif tradisional, distribusi tersebut dibagikan dalam bentuk barang-barang yang produktif. Contohnya adalah hewan ternak. Pemberian dalam bentuk produktif tersebut meciptakan suatu lapangan kerja bagi fakir miskin.

4). Distribusi produktif kreatif, distribusi tersebut diberikan dalam bentuk permodalan.

14 Riyantama Wiradifa, Desmadi Saharuddin. Strategi Pendistribusian Zakat, Infak, Sedekah (ZIS) Di Badan Amil Zakat Nasional (BAZNAS) Kota Tanggerang Selatan. Jurnal Ekonomi dan Bisnis Islam Vol.3 No.1. 2017. Hal 1-13

${ }^{15}$ M. Samsul Haidir. Revitalisasi Pendistribusian Zakat Produktif Sebagai Upaya Pengentasan
Tujuannya adalah untuk pembangunan proyek sosial dan penambahan modal usaha kecil.

\section{d. Langkah-Langkah Pendistribusian Zakat}

Ath-Thoilah dalam Abdullah
mengatakan bahwa terdapat
beberapa langkah dalam
pendistribusian zakat yaitu: ${ }^{15}$

1). Forecasting, forecasting yakni dengan meramalkan, memproyeksikan, dan mengadakan taksiran sebelum pemberian zakat.

2). Planning, planning bertujuan untuk merumuskan dan merencanakan suatu tindakan baik tujuan ataupun objek penerima zakat sebagai capaian suatu program.

3). Organizing dan leading, organizing dan leading yakni untuk mengumpulkan beberapa elemen seperti peraturan baku. Tujuannya adalah untuk membawa kesuksesan program.

4). Controlling, controlling berfungsi sebagai pengawasan terhadap jalannya suatu program.

\section{e. Ketentutan Pendistribusian Zakat}

Dalam pendistribusian zakat memiliki beberapa ketentuan yaitu: ${ }^{16}$

1). Distribusi domestic diutamakan untuk melakukan distribusi lokal. Penerima zakat yang dekat dengan

Kemiskinan Di Era Modern. Jurnal Muqtasid Vol.10 No.1. 2019. Hal 57-63

16 Teguh Ansori. Pengelolahan Dana Zakat Produktif Untuk Pemberdayaan Mustahik Pada Lazisnu Ponorogo. Muslim Heritage. Vol.3 No.1. Mei 2018. Hal 174 
lembaga zakat diutamakan dibandingkan dengan wilayah lain.

2). Pendistribusian zakat harus bersikap adil sesuai kaidahkaidah sebagai berikut:

a) Jika zakat terkumpul banyak, maka setiap golongan berhak menerima zakat sesuai kebutuhannya masing-masing.

b) Pendistribusian harus dilakukan secara menyeluruh sesuai dengan golongan yang ditentukan.

c) Zakat diperbolehkan untuk dibagikan kepada beberapa golongan saja. Syaratnya yakni bahwa kebutuhan golongan tersebut memerlukan penanganan khusus.

d) Golongan fakir miskin dijadikan sebagai golongan pertama penerima zakat.

e) Kepercayaan antara pemberi dan penerima zakat harus terbangun.

\section{f. Pola Pendistribusian Zakat Secara Profesional}

Yusuf Al-Qardhawi menjelaskan bahwa pola pendistribusian zakat terdapat beberapa macam yaitu: ${ }^{17}$

1). Pola Pendistribusian Produktif

Pola pendistribusian produktif adalah pola pemberian dana zakat yang dipinjamkan oleh amil untuk aktivitas usaha. Penyaluran tersebut bertujuan untuk merubah keadaan mustahik menjadi muzakki.

17 Hamidah dan Syahril Romli. Penditribusian Zakat Berbasis Ekonomi Pada Dompet Dhuafa Provinsi Riau. Idarotuna Vol. 1 No.2. April 2019.hal 74-75
2). Pendistribusian Secara lokal Pendistribusian ini merupakan pendistribusian yang mengutamakan lokasi penerima zakat. Jika tempat dari penerima zakat berada lebih dekat dengan lembaga zakat, maka penerima zakat tersebut didahulukan disbanding dengan penerima yang berada di wilayah lain.

3). Pendistribusian Adil Terhadap Semua Golongan

Keadilan dalam pendistribusian tersebut tidak bermaksud menyamaratakan antar golongan-golongan mustahik. Namun, keadilan yang memperhatikan hak, besarnya kebutuhan, dan kemaslahatan Islam yang tinggi.

\section{Efektivitas PendistribusianZakat}

\section{a. Pengertian Efektivitas}

Subagyo berpendapat bahwa efektivitas adalah kesesuaian antara output dan tujuan yang telah ditetapkan. Sehingga, efektivitas merupakan suatu kejadian yang terjadi karena dikehendaki. Efektivitas juga bermakna tentang kesesuaian antara hasil yang diharapkan dengan hasil yang telah dicapai. Secara garis besar bahwa efektivitas yaitu tercapainya keberhasilan dalam mencapai tujuan yang telah ditetapkan. ${ }^{18}$

${ }^{18}$ Mufti Afif, Sapta Oktiadi. Efektivitas Distribusi Dana Zakat Produktif dan Kekuatan Serta Kelemahannya Pada Baznas Magelang. Islamic Economics Journal Vol.4 No.2. Desember 2018. Hal 137 


\section{b. Efektivitas Pendistribusian Zakat}

Diantara berikut ini merupakan beberapa solusi dalam efektivitas pendistribusian zakat: ${ }^{19}$

1). Melakukan Penekanan

Kesenjangan Sosial zakat memiliki peran penting dalam menekan kesenjangan sosial dimasyarakat. Jika sistem zakat berjalan dengan efektif. Maka, hal tersebut akan terjadi penyempitan kesenjangan dan mendekatkan kelas ekonomi masyarakat yang satu dengan lainnya.

2). Melakukan Penekanan Terhadap Perilaku Monopoli

Islam memang mengakui adanya kesenjangan dalam persoalan kemampuan, keahlian kerja, dan tingkat pendapatan. Karena hal tersebut merupakan konsekuensi alamiah belaka dari kemampuan hingga potensi masing-masing orang. Namun, perilaku terhadap adanya kelaskelas sosial ekonomi tidak menggambarkan sikap sama rata sama rasa dalam sosialisme.

3). Melakukan Pengelolahan Ekonomi

Pada zaman sekarang ini, pengelolahan ekonomi menjadi tanggung jawab bersama antara pemerintah dan elemen masyarakat. oleh karena itu, pendistribusian zakat mempunyai peran penting untuk mengurangi angka kemiskinan. Masyarakat Islam tumbuh dan berkembang secara pesat.

19 Dr. Ilham, M.Pd.I. Efektivitas Pendistribusian dan pendayagunaan Dana Zakat Dalam Upaya Memberantas Kemiskinan. Jurnal Pemikiran Syariah dan Hukum Vol. 4 No.1. Maret 2020. Hal 8-14
Seiring dengan itu, sumber pendpatan juga ikut berkembang. Oleh karena itu, pengeluaran zakat juga ikut tumbuh dan berkembang.

4). Melakukan Pemberdayaan Terhadap Sumber Daya Manusia Negara memang mempunyai sumber daya alam yang melimpah. Oleh karena itu, pemerintah seharusnya memfasilitasi sumber daya manusia untuk melatih keterampilan dan mengolah SDA yang ada. Hal tersebut perlu adanya pembaharuan pemikiran. Sehingga, nantinya akan terbentuk manusiamanusia yang mandiri dan melaksanakan tatanan kehidupan sosial di negara ini.

\section{Zakat Produktif}

Zakat produktif adalah zakat yang diberikan kepada mustahik berupa barang. Barang tersebut memiliki nilai tambah. Zakat produktif dikatakan sebagai zakat harta atau dana zakat. zakat tersebut diberikan kepada mustahik dan tidak habis secara langsung. Zakat harta tersebut mampu dikembangkan seperti dalam aktivitas usaha. Sehingga, para mustahik mampu memenuhi kebutuhan hidupnya secara terus-menerus. ${ }^{20}$

\section{Mustahik}

\section{a. Pengertian Mustahik}

Mustahik merupakan orangorang yang berhak menerima zakat.

${ }^{20}$ Emi Hartatik. Analisis Praktik Pendistribusian Zakat Produktif Pada Badan Amil Zakat Daerah (BAZDA) Kabupaten Magelang. Az-Zarqa. Vol.7 No.1. Juni 2015. Hal 32 
Mustahik berasal dari kata haqqon yahiqqu hiqqon wa hiqqotan. Maksud dari kata tersebut adalah hak, kebenaran, dan kemestian. Isim fa'il dari mustahik yakni istihaqqo yastahiqqu istihqoq. Artinya adalah orang yang berhak atau menuntut hak. Afzalurrahman mengatakan bahwa kelompok penerima zakat telah ditentukan dalam Al-Qur'an. Oleh karena itu, Negara tidak mempunyai otoritas untuk menggunakan dana zakat selain kepada golongan yang telah disebutkan. ${ }^{21}$

Adapun orang-orang yang berhak menerima zakat adalah sebagai berikut: ${ }^{22}$
1) Orang-orang fakir
2) Orang-orang miskin
3) Para pengurus atau panitia zakat
4) Para muallaf yang dibujuk hatinya
5) Untuk memerdekakan budak
6) Orang-orang yang berhutang
7) Untuk jalan Allah
8) Orang yang sedang dalam perjalanan

\section{b. Kriteria Mustahik}

Ada dua kriteria mustahik yang dilihat dari penyebabnya: ${ }^{23}$

1) Ketidakmampuan dan ketidakberdayaan

Kategori ini dapat dibedakan berdasarkan dua hal. Pertama adalah ketidakmampuan dalam bidang Ekonomi. Beberapa contohnya adalah fakir, miskin, gharim, dan ibnu sabil. Harta zakat akan diberikan kepada mereka dengan tujuan untuk mengatasi kondisi perekonomiannya.

${ }^{21}$ Muzayyanah dan Heni Yulianti. Mustahik Zakat Dalam Islam. Al-Mizan Vol. 4 No. 1. Februari 2020. Hal 94-95

${ }^{22}$ Ibid
Kedua adalah ketidakberdayaan untuk mendapatkan hak asasi manusia. Hal ini bermaksud bahwa zakat diberikan untuk mengatasi ketidakbebasan dan keterbelengguan mereka dalam mendapatkan haknya sebagai manusia. Contohnya adalah budak.

2) Kemaslahatan Umum Umat Islam

Mustahik dalam kategori ini bukan karena ketidakmampuan dalam bidang financial. Namun, hal tersebut karena jasa dan tujuannya untuk kepentingan umat Islam. Contohnya adalah amil, muallaf, dan fi sabilillah. Amil mendapatkan dana zakat karena tugasnya sebagai pengelola dana zakat. Muallaf mendapat dana zakat karena memberi dukungan kepada umat Islam dan mengantisipasi umat Islam dari tindakan anarkis. Fi sabilillah diberikan dana zakat untuk semua kegiatan yang bermuara pada kemasahatan umat Islam

\section{UMKM}

\section{a. Pengertian UMKM}

Pengertian UMKM dibuat melalui UU No.9 Tahun 1999. Namun, karena keadaan perkembangan yang semakin dinamis dirubah ke UU No.20 Pasal 1 Tahun 2008 tentang usaha mikro, kecil, dan menengah. Oleh karena itu pengertian UMKM adalah sebagai berikut: ${ }^{24}$

1) Usaha Mikro

Usaha mikro adalah usaha produktif yang didirikan oleh

\footnotetext{
${ }^{23}$ Ibid

24 Yuli Rahmini Suci. Perkembangan UMKM (usaha mikro, kecil, menengah) di Indonesia. Jurnal Ilmiah Ekonomos Vol.6 No.1. Januari 2017. Hal 54
} 
perorangan atau badan usaha perorangan yang memenuhi kriteria usaha mikro sebagaimana diatur dalam undang-undang.

2) Usaha Kecil

Usaha kecil adalah usaha ekonomi produktif yang berdiri sendiri dan dilakukan oleh orang perorangan atau badan usaha. Badan usaha tersebut bukan termasuk cabang perusahaan yang dimiliki, dikuasai, atau menjadi bagian langsung ataupun tidak langsung dari usaha menengah atau usaha besar yang memenuhi usaha kecil sebagaimana dimaksud dalam undang-undang.

3) Usaha Menengah

Usaha menengah adalah usaha ekonomi produktif yang berdiri sendiri dan dilakukan oleh badan usaha orang perorangan. Usaha menengah juga bukan dilakukan oleh badan usaha anak perusahaan atau cabang perusahaan yang dikuasai, dimiliki, dan menjadi bagian baik langsung ataupun tidak langsung dengan usaha kecil atau usaha besar. Hal tersebut sebagaimana diatur dalam undang-undang.

4) Usaha Besar

Usaha besar merupakan usaha ekonomi produktif yang dilakukan oleh badan usaha dengan jumlah kekayaan bersih atau hasil penjualan tahunan lebih besar dari usaha menengah. Usaha besar meliputi usaha nasional milik Negara atau swasta, usaha patungan, dan usaha asing yang melakukan kegiatan ekonomi di Indonesia.

5) Dunia Usaha

Dunia usaha adalah Usaha Mikro, Usaha Kecil, Usaha Menengah, dan Usaha Besar yang melakukan kegiatan ekonomi di Indonesia dan berdomisili di Indonesia.

\section{Metode Penelitian}

Jenis penelitian yang digunakan peneliti adalah deskriptif kualitatif. Penelitian ini digunakan untuk meneliti masalahmasalah secara mendalam. Pada umumnya, format penelitian deskriptif kualitatif digunakan dalam bentuk studi kasus. Format penelitian ini memusatkan diri dari satu unit fenomena. Sehingga, kedalaman data ini mampu menjadi pertimbangan dalam penelitian. Tujuan jenis penelitian ini adalah untuk menggambarkan, meringkas berbagai kondisi atau situasi realitas sosial yang berada di masyarakat. ${ }^{25}$

Metode penelitian kualitatif merupakan metode yang mengumpulkan dan menganalisis data-data kulitatif yang berupa kata dan perbuatan manusia. Alasan penelitian kualitatif adalah untuk membongkar pikiran-pikiran yang tersimpan melalui pikiran-pikiran subjek penelitian. Pikiran-pikiran tersebut berisikan pengetahuan manusia yang tidak dapat disusun secara sistematis. Namun, hal tersebut bisa dilakukan dengan cara wawancara dan observasi. ${ }^{26}$ Dalam penelitian ini, peneliti bermaksud untuk mencari data-data sesuai dengan tujuan dan rumusan masalah. Dalam metode kualitatif, hasil data diinterpretasikan dan dikumpulkan dengan kalimat. 
Hasil dan Pembahasan

Kegiatan Pendistribusian Zakat Produktif Pemberdayaan UMKM di LAZISMU Kabupaten Gresik

Kegiatan pendistribusian zakat produktif pemberdayaan UMKM di LAZISMU Gresik merupakan kegiatan penyaluran zakat kepada para mustahik sesuai dengan anjuran agama Islam. kegiatan pendistribusian zakat produktif bertujuan untuk membantu para asnaf dalam meningkatkan potensi di bidang ekonomi. dari hasil penelitian, LAZISMU Gresik merupakan salah satu lembaga penampung dan pengelola zakat, infaq, dan sedekah yang berada di kota Gresik. Setelah dana dari masyarakat tersebut terkumpul, tugas LAZISMU Gresik yakni menyalurkan kepada para mustahik sesuai dengan aturan Islam.

Pendistribusian zakat merupakan kegiatan penyaluran dana zakat dari muzakki kepada mustahik. ${ }^{27}$ Erland Arif juga mengatakan bahwa pendistribusian zakat merupakan suatu proses penyaluran zakat yang terkumpul lalu diberikan kepada pihak-pihak tertentu. hal demikian berfungsi untuk meraih tujuan sosial dan ekonomi dari pemungutan zakat. ${ }^{28}$ Hasil penelitian tersebut sesuai dengan teori yang ada.

Sistem pendistribusian zakat produktif pemberdayaan UMKM di LAZISMU Gresik disalurkan secara langsung tanpa perantara dengan bekerja sama dengan pihak lain. Kegiatan pendistribusian zakat produktif biasanya dilakukan sendiri oleh karyawan lembaga dan dibantu oleh beberapa mahasiswa penerima beasiswa dari LAZISMU Gresik sebagai volunteer. Para volunteer tersebut tidak hanya menyalurkan saja. Namun,

${ }^{27}$ Emi Hartatik. Analisis Praktik Pendistribusian Zakat Produktif Pada Badan Amil Zakat Daerah (BAZDA) Kabupaten Magelang. Az-Zarqa. Vol.7 No.1. Juni 2015. Hal 33

28 Jeni Rahaman, Evi Martaseli. Pengaruh Pengendalian Internal Terhadap Pengelolaan dan mereka juga membantu untuk memenuhi kebutuhan-kebutuhan para penerima manfaat. Sehingga, bantuan yang diberikan bisa lebih efektif dan tidak disalahgunakan. Jenis-jenis distribusi memang dibagi menjadi dua. diantaranya adalah secara langsung dan tidak langsung. Sistem pendistribusian secara langsung merupakan sistem distribusi yang tidak membutuhkan perantara. Sedangkan sistem distribusi tidak langsung merupakan sistem distribusi yang menggunakan saluran distribusi atau perantara. ${ }^{29}$ Hasil penelitian di atas sesuai dengan teori yang dijelaskan.

Bentuk pendistribusian zakat dalam kegiatan pemberdayaan UMKM di LAZISMU Gresik memiliki dua cara. Diantaranya adalah distribusi produktif tradisional dan distribusi produktif kreatif. Dari hasil wawancara dengan beberapa narasumber, mereka mengemukakan bahwa LAZISMU Gresik mengutamakan untuk memberikan bantuan dalam bentuk barang dari pada uang tunai. Tujuannya adalah untuk menghindari adanya penyalahgunaan dana. Dana tersebut merupakan dana umat. Oleh karena itu, amanah harus dilaksanakan sesuai dengan akad.

Meskipun begitu, LAZISMU Gresik juga terkadang memberikan dalam bentuk uang tunai. Namun, LAZISMU Gresik tetap mengontrol dengan bantuan dari para volunteer. Para volunteer tersebut bertugas untuk mengawasi bagaimana uang tersebut digunakan. Jika calon UMKM tersebut memilih untuk membelanjakan uangnya sendiri. Maka, para volunteer memberikan waktu dan meminta berupa kwitansi.

Pendistribusian Zakat Pada Badan Amil Zakat Nasional Kota dan Kabupaten Sukabumi. Jurnal Ilmiah Ilmu Ekonomi. Vol.6 Edisi.12. Maret 2018. Hal 179

29 Westriningsih. 2018. Mengenal Kegiatan Distribusi. Klaten: Cempaka Putih. Hal 22 
M.Arif Mufraini mengatakan bahwa bentuk inovasi zakat terbagi menjadi empat macam. diantaranya adalah distribusi konsumtif tradisional, distribusi konsumtif kreatif, distribusi produktif tradisional, dan distribusi produktif kreatif. Distribusi konsumtif tradisional merupakan distribusi zakat yang dimanfaatkan secara langsung. Contohnya adalah zakat fitrah. Distribusi konsumtif kreatif adalah distribusi dalam bentuk barang. Contohnya adalah beasiswa. Distribusi produktif tradisional merupakan distribusi dalam bentuk barang produktif. Contohnya adalah hewan ternak. Dan distribusi produktif kreatif merupakan distribusi dalam bentuk permodalan. ${ }^{30}$ Hasil penelitian tersebut sesuai dengan teori yang tercantum.

Dalam pendistribusian zakat juga memiliki pola. Pola pendistribusian zakat LAZISMU Gresik menggunakan pola adil terhadap semua golongan. Dari hasil wawancara, para narasumber mengatakan bahwa LAZISMU tidak membandingbandingkan tentang golongan penerima zakat. jika lembaga menerima laporan. Maka, pihak lembaga segera menindaklanjuti laporan tersebut sesuai dengan prosedurenya. Pada dasarnya sesuai dengan nama lembaga dibawah naungan Muhammadiyah, LAZISMU awalnya mengutamakan jamaah Muhammadiyah. Namun, narasumber 1 sebagai kepala kantor berpendapat bahwa LAZISMU tidak mendahulukan golongan tertentu. semua mengikuti laporan yang masuk.

Yusuf Al-Qardlawi mengatakan bahwa pola pendistribusian zakat secara profesional terbagi menjadi tiga macam. pertama adalah pola pendistribusian zakat

30 Riyantama Wiradifa, Desmadi Saharuddin. Strategi Pendistribusian Zakat, Infak, Sedekah (ZIS) Di Badan Amil Zakat Nasional (BAZNAS) Kota Tanggerang Selatan. Jurnal Ekonomi dan Bisnis Islam Vol.3 No.1. 2017. Hal 1-13

31 Hamidah dan Syahril Romli. Pendistribusian Zakat Berbasis Ekonomi Pada Dompet Dhuafa produktif. Kedua adalah pola pendistribusian lokal. Ketiga adalah pola pendistribusian adil terhadap semua golongan. Pola pendistribusian produktif adalah pola pendistribusian zakat yang digunakan untuk aktivitas usaha. Pola pendistribusian lokal merupakan pola pendistribusian yang menguatamakan lokasi mustahik dekat dengan lembaga. Dan pola pendistribusian adil terhadap semua golongan merupakan pola pendistribusian yang bersifat merata. ${ }^{31}$

Teori lain juga menjelaskan bahwa ketentuan dalam pendistribusian zakat terdapat dua macam. pertama adalah distribusi domestic. Distribusi domestic tersebut mengutamakan penyaluran bantuan kepada mustahik yang jarak rumahnya dekat dengan lembaga dibandingkan yang lain. Kedua adalah pendistribusian zakat bersikap adil dan sesuai kaidah-kaidah. Pertama, jika zakat terkumpul banyak, maka setiap golongan menerima sesuai dengan kebutuhannya. Kedua, pendistribusian harus dilakukan secara menyeluruh. Ketiga, zakat diperbolehkan untuk diberikan kepada siapapun. Syaratnya yaitu kebutuhan golongan tersebut memang memerlukan penanganan khusus. Keempat, golongan fakir miskin dijadikan sebagai golongan pertama. Dan kelima, kepercayaan antara pemberi dan penerima terbangun. ${ }^{32}$

Data hasil wawancara diatas sesuai dengan teori yang ada. Hal tersebut terbukti bahwa pola pendistribusian LAZISMU Gresik menggunakan pola pendistribusian produktif dan pola pendistribusian secara adil terhadap semua golongan. Dalam paragraf selanjutnya akan dibahas mengenai golongan penerima zakat. Dalam pembahasan tersebut juga

Provinsi Riau. Idarotuna vol.1 No.2 April 2019. Hal 74-75

32 Teguh Ansori. Pengelolahan Dana Zakat Produktif Untuk Pemberdayaan Mustahik Pada Lazismu Ponorogo. Muslim Heritage Vol.3 No1. Mei 2018. Hal 174 
dijelaskan bahwa LAZISMU Gresik mengutamakan fakir miskin sebagai mustahik golongan pertama.

Dalam Islam, kegiatan pendistribusian zakat mempunyai aturan sendiri tentang golongan penerima zakat. Sama hanya dengan LAZISMU Gresik, kegiatan pendistribusian zakat tersebut diberikan kepada delapan asnaf sesuai dengan syariat Islam. Menurut hasil wawancara, golongan penerima zakat produktif dalam kegiatan pemberdayaan UMKM tersebut mayoritas diberikan kepada empat golongan. Diantaranya adalah fakir, miskin, gharim, dan fi sabilillah. Karena, tidak semua golongan mempunyai potensi untuk mengelola usaha. Oleh karena itu, LAZISMU Gresik melakukan seleksi dengan teliti untuk golongan penerima zakat produktif pemberdayaan UMKM tersebut.

Dalam surah At-Taubah ayat 60 berisi tentang golongan penerima zakat. diantaranya adalah fakir, miskin, amil, muallaf, memerdekakan hamba, gharim, sabilillah, dan ibnu sabil. 33 Hasil wawancara diatas sesuai dengan teori yang dijelaskan.

Zakat tidak bisa disalurkan kepada semua orang. Dalam Islam, golongan penerima zakat atau mustahik memiliki kriteria tersendiri. LAZISMU Gresik juga melakukan hal yang sama. Dalam proses pendistribusian zakat produktif, LAZISMU Gresik memiliki prosedure atau aturan yang harus dijalanka. Dari hasil penelitian, beberapa narasumber mengatakan bahwa LAZISMU Gresik memberikan bantuan zakat kepada mustahik yang tidak berdaya dan benarbenar tidak mampu. Hal tersebut sesuai dengan pernyataan beberapa narasumber, mereka mengemukakan bahwa dalam proses pendistribusian zakat produktif terdapat assessment. Dalam proses

33 Ahmad Sainul. Anak Yatim sebagai Mustahik Zakat. Jurnal El-Qanuny Vol.5 No. 1. Januari-Juni 2019. Hal 109-114 assessment tersebut, LAZISMU Gesik bertujuan untuk mengetahui kondisi sebenarnya dari calon penerima manfaat.

Selain itu, LAZISMU Gresik juga menekankan pada karakter calon penerima manfaat. LAZISMU Gresik memberikan bantuan bukan hanya untuk meningkatkan kesejahteraan dari mustahik tersebut. Namun, Lembaga juga berkeinginan untuk mewujudkan keluarga yang positif baik dari segi ekonomi, sosial, kesehatan, dan agama.

Mustahik memiliki dua kriteria yang dilihat dari penyebabnya. Pertama adalah ketidakmampuan dan ketidakberdayaan. Kedua adalah kemaslahatan umum umat Islam. ketidakmampuan mengarah pada bidang ekonomi. sedangkan ketidakberdayaan lebih mengarah untuk mendapatkan hak asasi manusia seperti budak. Selanjutnya adalah kemaslahatan umum umat Islam. maksud dari kemaslahatan umum umat Islam adalah bukan dalam hal ekonomi. Namun, hal tersebut dikarenakan sebaga jasa dan tujuannya untuk kepentingan umat Islam seperti amil dan fii sabilillah. ${ }^{34}$ Hasil penelitian di atas sesuai dengan teori yang dijelaskan.

Dalam proses pendistribusian zakat produktif pemberdayaan UMKM, LAZISMU Gresik juga mempunyai beberapa tahapan yang harus dilakukan sebelum bantuan disalurkan. Menurut beberapa narasumber, langkah pertama yang harus dilakukan adalah pendaftaran dan registrasi. Kedua, pihak lembaga atau para volunteer melakukan survei. LAZISMU Gresik memilik form assessment. Form tersebut berguna untuk penilaian dan skoring. Skoring diberikan untuk mengkategorisasikan mustahik sesuai dengan delapan asnaf. Kemudian, setelah dilakukan survei. Hasil dari survei tersebut diberikan kepada manajer

${ }^{34}$ Muzayanah dan Heni Yulianti. Mustahik Zakat Dalam Islam. Al-Mizan Vol.4 No.1 Februari 2020. Hal 94-95 
program dan kepala kantor. Hal tersebut bertujuan untuk koordinasi dan meramalkan seberapa banyak bantuan yang harus diberikan sesuai dengan kebutuhan calon penerima manfaat.

$$
\text { Ketiga, dalam kegiatan }
$$

pendistribusian zakat produktif pemberdayaan UMKM tentu memiliki perencanaan. Dalam persencanaan tersebut, LAZISMU Gresik memiliki tujuan sendiri dalam menjalankan kegiatan tersebut. Seperti pernyataan dari narasumber sebelumnya, mereka mengemukakan bahwa kegiatan pendistribusian zakat produktif tersebut dilakukan untuk meningkatkan ekonomi masyarakat yang kurang mampu sesuai dengan aturan dewan syariah.

Keempat, sebelum bantuan tersebut direalisasikan, LAZISMU Gresik melakukan pelatihan kepada calon penerima manfaat. Tujuannya adalah untuk membimbing calon penerima manfaat dalam pengelolahan usaha. Dalam pelatihan, calon penerima manfaat diberikan beberapa materi. Diantaranya adalah manajemen keuangan, materi ketakwaan, dan materi pemasaran. Jika ketiganya diikuti dengan baik juga disertai dengan niat yang sungguh-sungguh, maka usaha yang dikelola berjalan secara efektif.

Kelima, setelah pelatihan dan bantuan direalisasikan, pihak lembaga tidak akan melepaskan begitu saja. Menurut beberapa narasumber, mereka menegaskan bahwa pihak lembaa tetap melakukan monitoring untuk mengetahui perubahan yang sudah dialami. Bahkan, menurut pernyataan narasumber sebelumnya, ketika penerima manfaat atau mustahik membelanjakan kebutuhannya, para volunteer juga mengawasi dengan cara menemani mustahik. Hal tersebut meminimalisir terjadinya penyalahgunaan bantuan.

\footnotetext{
${ }^{35}$ M. Syamsul Haidir. Revitalisasi Pendistribusian Zakat Produktif Sebagai Upaya Pengentasan
}

$\begin{array}{rrr}\text { Ath-Thoilah dalam } & \text { Abdullah } \\ \text { mengemukakan } & \text { bahwa } & \text { dalam }\end{array}$ pendistribusian zakat terdapat beberapa langkah. Diantaranya adalah forecasting, planning, organizing juga leading, dan controlling. forecasting bertujuan untuk meramalkan, memproyeksikan, dan memberikan taksiran sebelum zakat diberikan. planning bertujuan untuk merumuskan perencanaan baik tujuan atau objek sebagai capaian program. organizing dan leading berguna untuk membawa kesuksesan program. dan controlling bertujuan untuk mengawasi jalannya suatu program. ${ }^{35}$ Data hasil wawancara tersebut sesuai dengan teori yang ada.

\section{Faktor-faktor Efektivitas Kegiatan Pendistribusian Zakat produktif Pemberdayaan UMKM di LAZISMU Kabupaten Gresik}

Efektivitas merupakan kesesuaian antara hasil yang diharapkan dengan hasil yang dicapai. Dalam setiap kegiatan atau program, tentu lembaga mempunyai perencanaan yang berisikan tujuan atau target. Hal tersebut berguna untuk mengetahui efektivitas kegiatan yang dijalankan. Sama halnya LAZISMU Gresik, kegiatan pendistribusian zakat produktif dibentuk bertujuan untuk meningkatkan potensi mustahik dalam bidang ekonomi. Beberapa narasumber mengatakan bahwa kegiatan pendistribusian zakat produktif bermaksud untuk mewujudkan mustahik yang mandiri dan bangkit. Selain itu, LAZISMU Gresik berharap kepada mustahik untuk bisa mengembangkan bantuan yang telah diberikan. Sehingga, bantuan tersebut mempunyai nilai tambah juga mampu mengubah mustahik menjadi muzakki.

Steers mengatakan bahwa ada enam elemen yang mempengaruhi efektivitas organisasi. pertama adalah penetapan tujuan strategis. Efektivitas

Kemiskinan Di Era Modern. Jurnal Muqtasid Vol.10 No.1. 2019. Hal 57-63 
berhubungan dengan kepentingan manajemen. Penentuan tujuan menjadi faktor yang utama. Hal tersebut bertujuan untuk mendapatkan dan mengatur sumber daya. Jika tujuan tersebut mendapat dukungan bersama. Maka, usaha yang tinggi akan dikerahkan untuk tercapainya tujuan yang telah ditetapkan. ${ }^{36}$ Data hasil wawancara tersebut sesuai dengan teori yang ada.

Sebuah kegiatan diperlukan sumber daya. Sumber daya berguna untuk menjalankan kegiatan sesuai perencanaan yang ditetapkan. Oleh karena itu dalam sebuah lembaga perlu untuk mencari sumber daya seperti para karyawan. LAZISMU Gresik dalam pelaksanaan kegiatan pendistribusian zakat pemberdayaan UMKM baisanya dilakukan oleh divisi program. Namun, LAZISMU Gresik hanya memiliki sdm yang minim. Sehingga, lembaga memerlukan bantuan yang lain seperti pencarian volunteer. Dari hasil wawancara dengan beberapa narasumber, mereka mengatakan bahwa LAZISMU Gresik dibantu oleh para volunteer yang terdiri dari beberapa mahasiswa. Para mahasiswa tersebut menjadi volunteer karena beasiswa yang diberikan oleh LAZISMU Gresik. Sehingga, dari awal mereka berkomitmen dan bertanggung jawab untuk membantu LAZISMU Gresik. Para volunteer biasanya bertugas di lapangan seperti survei, wawancara, assessment, dan mengontrol para mustahik. Sehingga, hal tersebut sangat memudahkan juga membantu lembaga dalam pelaksanaan kegiatan.

Steers juga mengemukakan bahwa elemen kedua dalam pengaruh efektivitas adalah pencarian dan pemanfaatan sumber daya. Ada tiga hal yang perlu diperhatikan dalam pencarian dan pemanfaatan sumber daya. Diantaranya adalah keharusan dalam

\footnotetext{
${ }^{36}$ Amir Syarifudin Kiwang, David D.W. Pandie,
} dan Frans Gana. Analisis Kebijakan dan Efektivitas integrasi dan koordinasi berbagai subsistem organisasi seperti subsistem produktif, pendukung, pemelihara, penyesuai dan manajemen. Selanjutnya adalah penetapan, implementasi, dan pemeliharaan pedoman-pedoman kebijakan. Dan terakhir adalah adanya serangkaian umpan balik dan lingkaran kendali untuk menjamin organisasi tetap pada target dalam pencapaian tujuan. Sehingga, sumber daya merupakan faktor yang kritis untuk menjalankan suatu kegiatan. ${ }^{37}$ Hasil wawancara diatas memang sesuai dengan teori yang tercantum.

Selanjutnya adalah lingkungan prestasi atau lingkungan kerja. Lingkungan kerja dalam sebuah organisasi memang mempunyai pengaruh besar terutama untuk kinerja para karyawan. Lingkungan kerja terbagi menjadi dua macam. diantaranya adalah lingkungan fisik dan non fisik. Menurut beberapa narasumber, LAZISMU Gresik mempunyai lingkungan fisik yang mendukung. Diantaranya adalah kantor cabang dengan fasilitas yang bagus, kantor layanan kecamatan, mobil layanan, serta para sdm yang ramah dan disiplin. Mobil layanan pun tidak hanya bagi para mustahik. Namun, LAZISMU Gresik juga mempunyai mobil dinas pribadi.

Sedangkan linkungan non fisik LAZISMU Gresik adalah hubungan kerja antara pimpinan dengan bawahan atau hubungan kerja antar pegawai. Dari beberapa narasumber menjelaskan bahwa LAZISMU Gresik selalu berkoordinasi dalam pelaksanaan kegiatan. Melalui observasi, peneliti juga merasakan bagaimana keramahan para pegawai. Mereka melayani dengan ramah, sopan, dan tentunya transparan.

Bahkan, hubungan antara kantor cabang dan kantor layanan di kecamatan juga selalu berkoordinasi. Mereka selalu

Organisasi. Jurnal Kebijakan dan Administrasi Publik vol (JKAP) Vol.19 No.1. Mei 2015. Hal 74 ${ }^{37}$ Ibid 
berusaha untuk bekerja sama dengan baik untuk mewujudkan tujuan yang telah ditetapkan. Contohnya adalah para ibu Aisiyah yang ikhlas dan cekatan untuk membantu LAZISMU Gresik dalam kegiatan pendistribusian zakat produktif pemberdayaan UMKM tersebut. Mereka sangat detail dan selektif. Sehingga, data yang didapatkan lebih valid. Mereka juga membantu dalam survei. Cara yang mereka lakukan dalam survei lebih kekeluargaan. Jadi, survei dilakukan tanpa ada rasa canggung terutama bagi mustahik yang dimintai keterangan.

Steers mengungkapkan bahwa elemen ketiga dalam pengaruh efektivitas adalah lingkungan prestasi atau lingkungan kerja. Mardiana berpendapat bahwa lingkungan kerja merupakan lingkungan tempat pegawai melakukan pekerjaannya sehari-hari. Lingkungan kerja yang kondusif akan mempengarui para pekerja untuk bekerja secara optimal. Selain itu, lingkungan kerja juga berhubungan dengan hubungan kerja antar sesama pegawai, hubungan kerja antara bawahan dan atasan, dan hubungan fisik tempat pegawai kerja. Secara garis besar, lingkungan kerja dibagi menjadi dua yakni lingkungan fisik dan non fisik. ${ }^{38}$ Oleh karena itu, data hasil wawancara bisa disebut sesuai dengan teori yang tertulis.

Faktor efektivitas dari sebuah kegiatan yang lain adalah proses komunikasi. Komunikasi merupakan alat untuk mengarahkan, memotivasi, memonitor, dan mengevaluasi kegiatan sesuai dengan tujuan yang telah ditetapkan. Dari hasil wawancara beberapa narasumber, LAZISMU Gresik memang memiliki beberapa kantor layanan yang berada di kecamatan. Sehingga, hal tersebut perlu adanya koordinasi antara pimpinan dan pegawai bahkan pegawai juga pegawai. Karena, jika kantor layanan mengalami kendala. Maka, hal tersebut bisa diambil alih oleh kantor cabang.

\footnotetext{
${ }^{38}$ ibid
}

Komunikasi mempunyai peran penting untuk mendukung efektivitas dan efisiensi kegiatan.

Narasumber juga mencontohkan bahwa pada saat para volunteer melakukan survei di lapangan. Mereka selalu berkoordinasi kepada manajer program lalu manajer program melaporkan kepada kepala kantor. Selain itu, evaluasi juga dilakukan rutin. Narasumber 1 dan 4 mengatakan bahwa evaluasi kegiatan pendistribusian zakat produktif biasanya dilakukan setiap tiga bulan sekali.

Elemen keempat pengaruh efektivitas menurut Steers adalah proses komunikasi. Proses komunikasi. Kerja sama yang baik dan jelas harus dibentuk melalui komunikasi yang baik antara unsur-unsur dalam organisasi tersebut. Komunikasi yang baik bisa mewujudkan suasa kenyamanan dan sikap pengertian dalam pekerjaan. Sendjaja menambahkan bahwa fungsi komunikasi dalam organisasi adalah sebagai fungsi informasi, fungsi regulasi, fungsi integrasi, dan fungsi persuasi. ${ }^{39}$ hal itu berarti hasil wawancara di atas sesuai dengan teori yang ada.

Sebuah organisasi tentu mempunyai pemimpin. Tugas pemimpin selain mengarahkan para pegawainya, pemimpin juga bertugas dalam pengambilan keputusan. Dalam kegiatan pendistribusian zakat produktif pemberdayaan UMKM lazismu Gresik, pemimpin mempunyai peran utama dalam persetujuan calon penerima manfaat. Tidak hanya kepada pegawai, pemimpin dalam kegiatan pendistribusian zakat produktif pemberdayaan UMKM juga bertugas untuk mengarahkan para penerima manfaat tentang bagaimana cara untuk mengelola sebuah usaha.

Narasumber 2 dan 3 menambahkan bahwa pemimpin selalu berusaha untuk menekankan kepada pegawainya tentang sikap jujur dan amanah. para pegawai didorong untuk bekerja secara maksimal.

${ }^{39}$ Ibid 
Alasannya, kegiatan pendistribusian zakat produktif tersebut merupakan dana dari masyarakat. Masyarakat atau muzakki memberikan amanah besar kepada lembaga untuk mengelola zakat dan menyalurkannya kepada pihak yang tepat.

Steers menyebutkan bahwa elemen kelima dari pengaruh efektivitas adalah kepemimpinan dan pengambilan keputusan. Kepemimpinan merupakan proses mengarahkan dan mempengaruhi pegawai untuk melakukan pekerjaan yang ditugaskan kepada mereka. Rost dalam Safaria mendefiniskan bahwa kepemimpinan diartikan sebagai sebuah hubungan yang saling berpengaruh antara atasan dan pegawai dalam pencapaian tujuan. Kepemimpinan dan pengambilan keputusan memegang peranan yang sentral dalam organisasi. Dalam organisasi, pemimpin memiliki banyak aktivitas seperti perencanaan kerja atau perumusan kerja, pemecahan masalah, dan lainnya. ${ }^{40}$

Selanjutnya adalah inovasi organisasi. inovasi dibuat untuk memprakarsai atau memperbaiki suatu produk dalam organisasi. begitun dengan kegiatan pendistribusian zakat produktif pemberdayaan UMKM, LAZISMU Gresik melalui pernyataan pemimpinnya mengatakan bahwa proses assessment dalam kegiatan pendistribusian zakat produktif tidak lagi menggunakan sistem manual melainkan sistem online. Para volunteer cukup hanya membawa tab ketika survei di lapangan. Hal tersebut memudahkan pemimpin untuk memantau meskipun pemimpin berada di kantor.

Lebih dari itu, pemimpin LAZISMU Gresik juga mengatakan bahwa lembaga akan bekerja sama dengan dinas kesehatan dan dinas koperasi. Pemimpin berharap kegiatan pendistribusian zakat produktif pemberdayaan UMKM tersebut bisa naik derajatnya. Jadi, para penerima

\footnotetext{
${ }^{40}$ Amir Syarifudin Kiwang, David D.W.Pendie, dan
} Frans Gana. Analisis Kebijakan dan Efektivitas manfaat diberikan edukasi tentang pentingnya kesehatan juga kebersihan dalam suatu usaha terutama usaha kuliner.

Narasumber 2 juga mengatakan bahwa dalam kegiatan pendistribusian zakat produktif terdapat beberapa hal yang harus diperhatikan. Diantaranya adalah karakter mustahik, mustahik anti perokok, dan MOU. LAZISMU Gresik menekankan bahwa calon penerima manfaat harus memiliki karakter yang baik. LAZISMU Gresik bekerja sama dengan aparat desa juga tetangga mustahik untuk memantau bagaimana karakter sebenarnya calon penerima manfat tersebut. LAZISMU Gresik juga tidak menerima mustahik perokok. Karena, LAZISMU Gresik tidak hanya mengingkan kesejahteraan ekonomi mustahik tapi juga ingin membentuk keluarga yang sehat dan berkarakter baik. Terakhir adalah MOU. Jika bantuan tersebut sudah direalisasikan, maka penerima manfaat harus berkomitmen kepada lembaga. Contohnya dalam kurun waktu enam bulan, keluarga yang perokok harus berhenti. Ibadahnya pun juga harus ditingkatkan minimal shalat lima waktu.

Elemen terakhir pengaruh efektivitas menurut Steers adalah inovasi organisasi. Van de Ven mengatakan bahwa mengartikan bahwa inovasi merupakan suatu gagasan baru yang diterapkan untuk memperbaiki suatu produk, proses, atau jasa. ${ }^{41}$ Data hasil penelitian di atas sesuai dengan teori yang tercantum.

\section{Kesimpulan}

Bentuk kegiatan pendistribusian zakat produktif pemberdayaan UMKM LAZISMU Gresik merupakan kegiatan yang bergerak untuk meningkatan potensi masyarakat dalam bidang ekonomi. sistem pendistribusian zakat produktif juga dilakukan secara langsung oleh pihak LAZISMU Gresik. Bentuk pendistribusian

Organisasi. jurnal Kebijakan dan administrasi publik (JKAP) Vol.19 No. 1. Mei 2015. Hal 75-76 ${ }^{41}$ Ibid 
zakat produktif pemberdayaan UMKM LAZISMU Gresik diberikan dalam bentuk barang. Barang tersebut nantinya bisa dikembangkan menjadi sebuah usaha. Sehingga, nilainya terus bertambah. Pola pendistribusian zakat produktif di LAZISMU Gresik menggunakan pola adil terhadap semua golongan. Golongan penerima zakat produktif tersebut juga disesuaikan sesuai syariah Islam. Namun, LAZISMU Gresik lebih mempriortaskan kepada golongan yang masih mampu untuk diberdayakan. Contohnya adalah miskin, gharim, dan fii sabilillah. Karakter mustahik juga sangat diperhatikan. Selain karena ketidakberdayaan dan ketidakmampuan, LAZISMU Gresik juga menekankan pada karakter mustahik. Kegiatan pendistribusian zakat produktif permberdayaan UMKM tersebut dijalankan juga sesuai beberapa tahapan yang sudah ditetapkan oleh LAZISMU Gresik.

Ada beberapa faktor yang mempengaruhi efektivitas kegiatan pendistribusian zakat produktif pemberdayaan UMKM LAZISMU Gresik. Pertama adalah target atau tujuan. Kedua adalah pencarian dan pemanfaatan SDM. ketiga adalah lingkungan prestasi atau lingkungan kerja. Keempat adalah proses komunikasi. Kelima adalah kepemimpinan dan pengambilan keputusan. Keenam adalah inovasi organisasi.

\section{Daftar Pustaka}

Ahmad Dahlan. 2008. Keuangan Publik Islam: Teori dan Praktik. (Yogyakarta:Grafindo Litera Media).

Ahmad Sainul. Anak Yatim sebagai Mustahik Zakat. Jurnal ElQanuny Vol.5 No. 1. JanuariJuni 2019.
Amir Syarifudin Kiwang, David D.W. Pandie, dan Frans Gana. Analisis Kebijakan dan Efektivitas Organisasi. Jurnal Kebijakan dan Administrasi Publik vol (JKAP) Vol.19 No.1. Mei 2015.

Dr. Ilham, M.Pd.I. Efektivitas Pendistribusian dan pendayagunaan Dana Zakat Dalam Upaya Memberantas Kemiskinan. Jurnal Pemikiran Syariah dan Hukum Vol. 4 No.1. Maret 2020.

Emi Hartatik. Analisis Praktik Pendistribusian Zakat Produktif Pada Badan Amil Zakat Daerah (BAZDA) Kabupaten Magelang. Az-Zarqa. Vol.7 No.1. Juni 2015.

Hamidah dan Syahril Romli. Penditribusian Zakat Berbasis Ekonomi Pada Dompet Dhuafa Provinsi Riau. Idarotuna Vol. 1 No.2. April 2019.

Imam Heryanto. Analisis Pengaruh Produk, Harga, Distribusi, dan Promosi Terhadap Keputusan Pembelian Serta Implikasinya Pada Kepuasan Pelanggan. Jurnal Ekonomi, Bisnis, dan Entrepreneurship. Vol.9 No.2. Oktober 2015.

Jeni Rahaman, Evi Martaseli. Pengaruh Pengendalian Internal Terhadap Pengelolaan dan Pendistribusian Zakat Pada Badan Amil Zakat Nasional Kota dan Kabupaten Sukabumi. Jurnal Ilmiah Ilmu Ekonomi. Vol.6 Edisi.12. Maret 2018.

Merry Agustina, Fina Oktasari. Penerapan Metode DRP (Distribusi 
Requirement Planning) Pada Sistem Informasi Distribusi LPG (Studi Kasus : PT Bumi Sriwijaya Palembang). Seminar Nasional Informatika UPN "Veteran" 2012. Vol.1 No.4. Yogyakarta 30 Juni 2015. Hal 77

M. Samsul Haidir. Revitalisasi Pendistribusian Zakat Produktif Sebagai Upaya Pengentasan Kemiskinan Di Era Modern. Jurnal Muqtasid Vol.10 No.1. 2019.

Muzayyanah dan Heni Yulianti. Mustahik Zakat Dalam Islam. Al-Mizan Vol. 4 No. 1. Februari 2020.

Mufti Afif, Sapta Oktiadi. Efektivitas Distribusi Dana Zakat Produktif dan Kekuatan Serta Kelemahannya Pada Baznas Magelang. Islamic Economics Journal Vol.4 No.2. Desember 2018.

Prof. Dr. H. M. Burhan Bungin,S.Sos.,M.Si. 2011.Penelitian Kualitatif:Komunikasi, Ekonomi, kebijakan Publik, dan $\operatorname{lmu}$ Sosial Lainnya.Jakarta:Kencana.

Riyantama Wiradifa, Desmadi Saharuddin. Strategi Pendistribusian Zakat, Infak, Sedekah (ZIS) Di Badan Amil Zakat Nasional (BAZNAS) Kota Tanggerang Selatan. Jurnal Ekonomi dan Bisnis Islam Vol.3 No.1. 2017.

Tika Widiastuti. Model Pendayagunaan Zakat Produktif Oleh Lembaga Zakat Dalam Meningkatkan
Pendapatan Mustahik. JEBIS. Vol.1 No.1.2015.

Teguh Ansori. Pengelolahan Dana Zakat Produktif Untuk Pemberdayaan Mustahik Pada Lazisnu Ponorogo. Muslim Heritage. Vol.3 No.1. Mei 2018.

Westriningsih. 2018. Mengenal Kegiatan Distribusi. Klaten:Cempaka Putih.

Yuli Rahmini Suci. Perkembangan UMKM (usaha mikro, kecil, menengah) di Indonesia. Jurnal Ilmiah Ekonomos Vol.6 No.1. Januari 2017. 